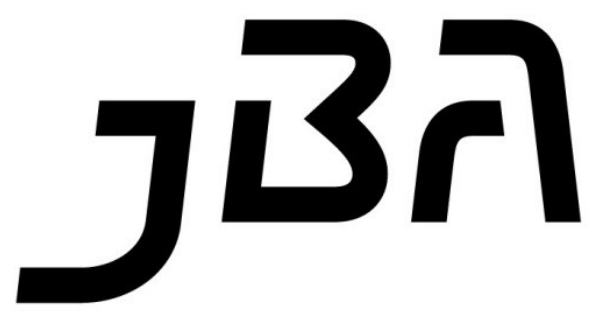

\title{
Rethinking the MBA: a Turn to the Field within Business Education?
}

Review Essay by Karl Palmås

In The Transformation of Corporate Control, Neil Fligstein (1990) charts the rise of what he terms "the finance conception of control" within American business. Prior to this mid-20 $0^{\text {th }}$ century development, management was framed in terms of sales expansion and product diversification. However, as corporations had grown to the point where an executive could hardly be expected to know the specifics of each product, financial analysis became the primary mode of decision-making. Thus, businesses were to be run along the

Page 1 of 4

JBA Review Essay Spring 2013

(C) The Author(s) 2013 ISSN 2245-4217

www.cbs.dk/jba lines of metrics such as return on investment, which implied that decisions could be made in a cool, detached and analytic manner.

Srikant Datar, David Garvin and Patrick Cullen, authors of Rethinking the MBA: Business education at a crossroads (Boston: Harvard Business School, 2010 ), suggest that this very mode of decision-making has had detrimental effects on contemporary business life. Writing in the context of the 2009 financial crisis, they assert that in recent years, managers have "relied too heavily on mathematical risk models and not enough on good judgment". This, in turn, is a reflection of the curricula of American business schools. As one of the business school deans interviewed for the book contends: "We have created students who are smart, but not necessarily as street smart and skeptical as they should be." Thus, when introducing the core argument of their book, the authors posit that today's MBA programs should focus on developing "effective leaders and entrepreneurs, as opposed to individuals trained primarily in analysis". This, in turn, necessitates a rebalancing of the business school curricula. The analysis-centric case study pedagogy - still avidly promoted by 
Harvard Business School, the home institution of the authors - ought to be complemented with different versions of field-based learning.

Rethinking the $M B A$ was released just prior to Harvard Business School's highly publicized introduction of a "field immersion" component within their own MBA program. As such, the text could be interpreted as a marketing pamphlet rather than an inquiry into where American business education is heading. Nevertheless, the argument rests upon a large number of in-depth interviews with deans from other top business schools, as well as business executives, and these voices seem to agree on the need for more fieldwork. The book also highlights a number of other business schools that are currently experimenting with field-based pedagogies. This, as well as the sheer influence of HBS itself, suggests that a term like "the turn to the field" is relevant in this account.

This rebalancing of business school pedagogy does not necessarily amount to a shift in learning objectives. Case-based pedagogy has long been construed as a forging of judgment (Christensen, Garvin \& Sweet, 1992), and Rethinking the MBA also extols this virtue. The turn to the field, however, implies a different conception of the context within which good judgment is to be shown. Case study pedagogy presents students with a world of pre-defined, clearly targeted problems. Starting from there, they can apply their "spreadsheets, decision trees, financial models, and high-powered statistical methods", and then debate each other on what routes to pursue. In contrast, the field presents students with a world of "unstructured problems, ambiguous data, rapidly changing environments, and information overload". Fieldwork thus forces students into problem-finding in perplexing situations. Here, the authors' description of the contemporary business world resembles that of Stark's (2009) description of "hetarchies", characterized by a confusion and disagreement regarding "what counts".

What, then, is implied by the term "fieldwork"? Most of the pedagogical initiatives highlighted in Rethinking the $M B A$ do not measure up to the lengthy stays in the field as required in anthropology. The authors single out two field immersion courses currently offered by leading business schools: The International Entrepreneurship Lab at Booth School of Business (University of Chicago), and the Multidisciplinary Action Projects at the Ross School of Management (University of Michigan). The former case involves a field-based preparation of a plan for a new business, in sites like China. However, the field visit is only ten days, and does not involve the creation of an actual business. In the latter case, students spend seven weeks working for and with partnering enterprises across the globe. There are, however, other MBA programs that take field component further. For instance, the Global Social and Sustainable Enterprise MBA at Colorado State University - not mentioned in the book grants students ten weeks of fieldwork. The field experience is documented and reported upon, and this material then serves as a context for a business plan that can be implemented after graduation. However, though the fieldwork component may be limited, the authors' rationales for heading to the field are somewhat more aligned with those of anthropologists. Not only must students' theory-driven mode of thinking be "challenged" by perplexing situa- 
tions in the field, it is also imperative that the new generation of MBA students are well attuned to a globalized, multicultural business world. Thus, "cultural sensibility", "cultural awareness", and "cultural intelligence" must be developed, along with a capacity to "interpret cultures other than one's own".

It is tempting to place this development within business education alongside the recent debates on the Human Terrain System, and more generally the use of anthropology within the American military. (Network of Concerned Anthropologists, 2009) Indeed, Rethinking the MBA borrows its general leadership education framework - which sees a shift from analytical "knowing" to reflective and attentive "being" - from the US Army, which uses it at the United States Military Academy at West Point. This, in turn, should be seen in the context of a tradition within which business educators import perspectives and techniques from the military. For instance, the founding of "management science" and numerical-analytic approaches such as operations research were directly sourced from military think tanks (DeLanda, 1991). In a similar vein, Byrne (1993) suggests that the above-mentioned advent of the "financial conception of control" is epitomized by the career path of the young Robert McNamara. Originally an assistant professor in accounting at Harvard Business School, he developed and pioneered numerical analysis at the US Air Force. Post-war, he introduced the same type of mathematical "stat control" at Ford Motor Company. Will future business historians present similar stories of the introduction of anthropology-inspired modes of management?

Like the introduction of the Human Terrain Systems, the turn to the field within business education raises ethical issues. The fact that MBA students are increasingly heading to the field in far-away places is, of course, nowhere near as problematic as the use of anthropology in counter-insurgency warfare. Nevertheless, the turn to the field within business education necessitates a deeper engagement with issues that anthropology has long wrested with. As such, it is imperative that the business school students in question are subjected to questions that most "Anthropology 101" students face: What does it mean to study "cultures other than one's own", and what can we learn from historical endeavors to do so? This point becomes all the more important if we consider that business schools may well extend the "field immersion" components of their programs. We may also see action-based entrepreneurship programs gravitate towards fieldwork, allowing students to explore venture creation in non-orthodox business settings, and then write up their experiences. Such "anthropreneurship" students would not only need a good grasp of the ethics of doing fieldwork; they also need to be proficient in ethnographic methods.

There are, nevertheless, limits to such radical rebalancing in curricula. The turn to the field may become excessively expensive for business schools, not least because field-based tutoring and fieldwork supervision is labor intensive. Such issues notwithstanding, the developments sketched above point to the fact that business anthropologists are acutely needed within business schools. Their expertise may counter potential perils presented by the increased interest in field immersion, and they may well assist in new modes of learning. Thus, books like Rethinking the MBA may not add to the current dis- 
cussions within business anthropology or organizational ethnography, but it may well alter the professional landscape for scholars working within these disciplines. Thus, business anthropologists and ethnographers - especially those working in the proximity of business schools - may want to acquaint themselves with the emerging literature on the turn to the field. Having done so, they can decide whether or not it will make a suitable gift to the dean of the nearby business school.

\section{References}

Byrne, J.A. 1993 The Whiz Kids: Ten founding fathers of American business and the legacy they left us. New York, NY: Doubleday.

Christensen, C.R., D. Garvin \& A. Sweet 1992 Education for Judgment: The artistry of discussion leadership. Boston, MA: Harvard Business School Press.

Datar, S., D. Garvin \& P. Cullen, 2010 Rethinking the MBA: Business education at a crossroads. Boston, MA: Harvard Business School Press.

DeLanda, M. 1991 War in the Age of Intelligent Machines. New York, NY: Zone Books.

Fligstein, N. 1990 The Transformation of Corporate Control. Cambridge, MA: Harvard University Press.

Fligstein, N. 1990 The Transformation of Corporate Control. Cambridge, MA.: Harvard University Press.

Network of Concerned Anthropologists. 2009 The Counter-Counterinsurgency Manual. Chicago, IL: Prickly Paradigm Press.

Stark, D. 2009 The Sense of Dissonance: Accounts of worth in economic life. Oxford: Princeton University Press.

Karl Palmås holds a PhD in sociology from the London School of Economics. He is an associate professor at the Division of Management of Organizational Renewal and Entrepreneurship (MORE), at Chalmers University of Technology (Gothenburg, Sweden). Karl's research focuses on innovation, entrepreneurship and social change. He may be reached at karl.palmas@chlamers.se. 